\title{
DUCHOWOŚĆ MIŁOSIERDZIA WEDŁUG PAPIEŻA FRANCISZKA
}

\section{THE SPIRITUALITY OF MERCY ACCORDING TO POPE FRANCIS}

A b s t r a c t. Thanks to the last popes, especially Francis, a characteristic feature of the Catholic Church in the third millennium is the cult of God's mercy. It requires the formation of appropriate spiritual attitudes, which in contemporary theology of spirituality are described by pointing to their cognitive, axiological-affective, and practical-action aspects.

The theme of mercy permeates the life of the Church so deeply that we can speak not only of the spirituality of mercy, but also of the merciful dimension of Christian spirituality.

The cult of God's mercy is closely related to the liturgy, therefore - especially the Eucharistic liturgy - it also has a merciful dimension. Therefore, shaping the attitudes of mercy has its source in it.

Keywords: spirituality; mercy; spiritual attitude; liturgy; pope Francis.

Obecna w Biblii od początku prawda o Bogu bogatym w miłosierdzie, w ostatnich dziesięcioleciach bardzo ożyła w świadomości eklezjalnej i stała się popularna w duchowości Kościoła katolickiego głównie za sprawą prywatnych objawień św. Faustyny Kowalskiej, opisanych w jej Dzienniczku.

Wielkie zasługi w tym względzie ma św. Jan Paweł II, który jeszcze jako arcybiskup Krakowa inspirował najbardziej wytrawnych teologów polskich do

Ks. prof. dr hab. MAREK ChMIELEWSKI - kierownik Katedry Duchowości Systematycznej i Praktycznej, Wydział Teologii Katolickiego Uniwersytetu Lubelskiego Jana Pawła II; wiceprezes Polskiego Stowarzyszenia Teologów Duchowości; przewodniczący Polskiego Towarzystwa Mariologicznego; adres do korespondencji: Al. Racławickie 14, 20-950 Lublin; e-mail: cechaem@kul.pl; ORCID: https://orcid.org/0000-0001-7566-5072. 
wnikliwej refleksji nad tą prawdą. Wydatnie przyczynił się do cofnięcia przez Stolicę Apostolską notyfikacji z 1959 r. zakazującej tego kultu w formach zaproponowanych przez krakowską mistyczkę. Ponadto doprowadził do rewizji transkryptu Dzienniczka i poddania go wnikliwej analizie teologicznej ${ }^{1}$. Po wyborze na tron Piotrowy wydał przełomową encyklikę Dives in misericordia (z 30 XI 1980), w której wprawdzie nic nie wspomniał o formie kultu, jaką św. Faustyna otrzymała w objawieniach, ale dał mocną podbudowę teologiczną i przygotował grunt pod jego upowszechnienie, co stało się faktem w związku z jej beatyfikacją (18 IV 1993) i kanonizacją (30 IV 2000). W swoich alokucjach często podejmował temat miłosierdzia Bożego. Podczas ostatniej pielgrzymki do Polski, 17 VIII 2002 r. poświęcił bazylikę Bożego miłosierdzia w krakowskich Łagiewnikach, ustanawiając ją światowym centrum tego kultu, a zarazem zlecając Kościołowi w Polsce misję rozszerzania go po całym świecie, zgodnie z zapowiedzią Chrystusa w jednym z objawień zapisanych przez św. Faustynę, że z Polski „wyjdzie iskra” (Dz 1732; Jan Paweł II, 2008). Znamienne jest to, że św. Jan Paweł II zmarł w wigilię Niedzieli Miłosierdzia Bożego - 2 IV 2005 r.

Jego śladem poszli następcy. Benedykt XVI wielokrotnie powracał do kwestii miłosierdzia Bożego, pogłębiając ją teologicznie, między innymi w encyklice Deus caritas est (z 25 XII 2005) i w innych swoich wypowiedziach (Warzeszak, 2016; Jędrzejski, 2017). Natomiast Franciszek, dopełniając dzieła swego wielkiego poprzednika, ustanowił Nadzwyczajny Jubileusz Miłosierdzia, który trwał od uroczystości Niepokalanego Poczęcia - 8 XII 2015 r. do uroczystości Chrystusa Króla Wszechświata - 20 XI 2016 r. Obficie czerpiąc z myśli św. Jana Pawła II, wydał bullę pt. Misericordiae vultus (z 11 IV 2015), w której zapowiedział wspomniany Jubileusz. Czytamy w niej między innymi, że konieczna i zarazem ,możliwa jest kontemplacja miłosierdzia Boga i przyjęcie go jako własnego stylu życia” (nr 13).

Pisząc o stylu życia, papież zapewne ma na myśli kształt postaw, przez które rozumie się to wszystko, co zawiera się w pojęciu „duchowość”, w tym

\footnotetext{
${ }^{1}$ Na skutek licznych uchybień przy transkrypcji rękopisu Dzienniczka św. Faustyny Kowalskiej, Kongregacja Świętego Oficjum 6 III 1959 r. wydała notyfikację zakazującą tego kultu. To skłoniło teologów do poddania pod refleksję prawdy o Bożym miłosierdziu, jak również wnikliwej analizy samego Dzienniczka. Istotne znaczenie miała opinia ks. Ignacego Różyckiego zawarta m.in. w opracowaniach: Zasadnicze rysy nabożeństwa do Miłosierdzia Bożego (Kraków, 1982) i Nabożeństwo do Miłosierdzia Bożego, studium teologiczne „Dzienniczka” bt. Siostry Faustyny Kowalskiej na temat Nabożeństwa (Kraków, 1999), jak również sympozja i kongresy organizowane w latach 1966-1992 przez Ośrodek Studium Miłosierdzia Bożego w częstochowskiej Dolinie Miłosierdzia.
} 
przypadku - „duchowość miłosierdzia”. Poświęcił jej wiele uwagi również w liście apostolskim Misericordia et misera (z 20 XI 2016), wydanym na zakończenie Nadzwyczajnego Jubileuszu Miłosierdzia, oraz w licznych wypowiedziach na temat Bożego miłosierdzia. Na uwagę zasługuje książka papieża pt. Miłosierdzie to imię Boga. Rozmowa z Andrea Torniellim (Kraków 2016).

Powszechność kultu Bożego miłosierdzia w kształcie, jaki wyrasta z treści Dzienniczka św. Faustyny Kowalskiej, potwierdza, że duchowość miłosierdzia oddaje istotę Kościoła, a ponadto jest adekwatną odpowiedzią na głęboki kryzys antropologiczny naszych czasów, który św. Jan Paweł II nazwał „chorobą horyzontalizmu" (por. EiE 34). Przejawia się ona głównie utratą nadziei i chrześcijańskiej pamięci, a co za tym idzie - swego rodzaju lękiem przed przyszłością, wewnętrzną pustką dręczącą wielu ludzi i utratą sensu życia, „fragmentaryzacją egzystencji”, poczuciem osamotnienia, coraz liczniejszymi podziałami i kontrastami oraz wieloma innymi zjawiskami o charakterze destrukcyjnym (por. EiE 7-8; Chmielewski, 2006; Chmielewski, 2014).

W tym kontekście duchowość miłosierdzia, która na przełomie tysiącleci stała się jednym z wiodących nurtów życia eklezjalnego, zdaje się być skutecznym remedium na bolączki współczesnego świata. Wyraźnie wskazuje na to Franciszek w swoim nauczaniu o miłosierdziu. Śledząc je, można nakreślić główne rysy duchowości miłosierdzia, czyli stylu życia chrześcijańskiego ożywianego tą prawdą wiary. Nie zamierzamy zatem w niniejszym opracowaniu zajmować się całą tematyką miłosierdzia, gdyż z okazji Nadzwyczajnego Jubileuszu powstała bogata literatura na ten temat. Chcemy natomiast wskazać na miłosierdzie, jako zasadniczą postawę duchową chrześcijanina.

\section{MIŁOSIERDZIE JAKO POSTAWA DUCHOWA}

Dzieło promocji kultu Bożego miłosierdzia, podjęte przez św. Jana Pawła II, z dużym zaangażowaniem kontynuuje Franciszek, obficie czerpiąc z doktrynalnego wkładu swego świętego poprzednika. O ile jednak encyklika Dives in misericordia, uznawana za magna charta teologii, duchowości i kultu miłosierdzia Bożego, ma raczej charakter systematycznego traktatu dogmatycznego, to bulla Misericordiae vultus i list apostolski Misericordia et misera zawierają liczne pastoralne i praktyczne odniesienia do życia chrześcijańskiego. Można więc powiedzieć, że są bardziej traktatami ascetyczno-duchowymi, w których papież zawarł nie tylko przesłanki dogmatyczne, wyłożone przez swego poprzednika, ale także wskazał na racje aksjologiczne z usilną zachętą do przeżywania Roku Miłosierdzia, jak również zaproponował szereg 
konkretnych działań mających na celu doprowadzenie współczesnego człowieka do doświadczenia prawdy o miłosiernej miłości Boga.

Wśród wielu okoliczności, które realnie wpływają na treść i jakość doświadczenia duchowego, jest społeczna marginalizacja, która znalazła się w centrum uwagi papieża. Sytuację marginalizacji społecznej określa on jako „peryferie egzystencji”" . Nie wykluczają one doświadczenia duchowego, które może owocować bogatym życiem duchowym, lecz przeciwnie - stanowią wyjątkową okoliczność, dzięki której może rozwijać się duchowość miłosierdzia. Temu celowi miał służyć między innymi ustanowiony Jubileuszowy Rok Miłosierdzia i związane z tym papieskie nauczanie. Poddając je analizie teologicznej można dojść do wniosku, że w pełni zasadna jest teza o specyficznej duchowości miłosierdzia. A ponieważ ta prawda przenika wszystkie aspekty życia Kościoła, z liturgią włącznie, więc nie pozbawioną racji jest również teza o miłosierdziowym wymiarze współczesnej duchowości chrześcijańskiej i życia chrześcijańskiego w ogóle ${ }^{3}$.

Dla wykazania tego posłużymy się metodą wypracowaną w środowisku polskich teologów duchowości. Polega ona na wskazaniu postaw, które mają do przedmiotu doświadczenia duchowego trojakie odniesienie: poznawcze, aksjologiczno-afektywne i praktyczno-działaniowe. Duchowość, w sensie ogólnym, a szczególnie duchowość religijną, a więc również chrześcijańską, rozumie się bowiem jako zespół postaw, czyli względnie stałych poglądów, wartościowań, decyzji i działań, ujmowanych w aspekcie poznawczym, aksjologiczno-afektywnym i działaniowym (Chmielewski, 2010b). Odpowiednio do tego o duchowości miłosierdzia (duchowości miłosierdziowej) można mówić

${ }^{2}$ To plastyczne i adekwatne określenie nierzadko pojawia się w alokucjach i dokumentach papieża Franciszka. Najczęściej, bo 9 razy występuje w adhortacji Evangelii gaudium o głoszeniu Ewangelii we współczesnym świecie (z 24 XI 2013). Po jednym razie zostało użyte w Liście apostolskim do wszystkich osób konsekrowanych z okazji Roku Życia Konsekrowanego (z 21 XI 2014), Orędziu na Światowy Dzień Młodzieży 2014 i w bulli Misericordiae vultus $\mathrm{w}$ numerze 15 .

${ }^{3}$ Wydaje się, że bardziej poprawnym jest mówić - na przykład - nie tyle o duchowości eucharystycznej, maryjnej czy miłosierdzia, co raczej o eucharystycznym, maryjnym czy miłosierdziowym wymiarze duchowości chrześcijańskiej. Te i inne style życia duchowego nie stanowią odrębnych duchowości, lecz pozostają względem siebie komplementarne i eksponują różne aspekty jednej co do istoty duchowości chrześcijańskiej. Gdy chodzi o maryjność, to zarówno św. Jan Paweł II jak i Papieska Międzynarodowa Akademia Maryjna w dokumencie Matka Pana. Pamięć - obecność - nadzieja. Niektóre aktualne zagadnienia dotyczace postaci i misji Najświętszej Dziewicy Maryi (Watykan, 2000) wyraźnie opowiadają się za maryjnym wymiarem duchowości chrześcijańskiej (Chmielewski, 2010a). To samo dotyczy miłosierdziowego wymiaru duchowości katolickiej (Matulewicz, 2007). 
wówczas, gdy chrześcijanin w Chrystusie rozpoznaje Oblicze Boga jako Ojca bogatego w miłosierdzie (miłosierdzie doznawane); gdy uznaje, że zasługuje, by być ogarniętym przez Jego miłosierdzie i pozwala się temu miłosierdziu ogarnąć (miłosierdzie uznawane); a wreszcie - gdy odpowiadając na rozpoznany i przyjęty dar miłości miłosiernej - podejmie czyny miłosierdzia (miłosierdzie świadczone).

\subsection{ASPEKT POZNAWCZY DUCHOWOŚCI MIŁOSIERDZIA}

Jeśli chodzi o pierwsze z odniesień, to - jak zauważa jeden z autorów „podstawą duchowości miłosierdzia jest objawiona przez Jezusa Chrystusa prawda o Bożym miłosierdziu”, wobec tego ,intelektualno-poznawczy wymiar duchowości człowieka sprowadzać się będzie do poznania przez niego prawdy o miłosierdziu Bożym" (Wejman, 1999).

Jak wynika z Objawienia i opartego na nim nauczania Kościoła, miłosierdzie stanowi najwyższy przymiot Boga i jest głęboko zakorzenione w tajemnicy Przenajświętszej Trójcy oraz misterium Wcielenia. Daje temu wyraz zarówno św. Jan Paweł II, jak i Franciszek. Pierwszy pisze, iż „bogaty w miłosierdziu swoim Bóg" (por. Ef 2,4) jest Tym, którego objawił nam Jezus Chrystus jako Ojca" (DiM 1). Z kolei Franciszek swą bullę rozpoczyna stwierdzeniem, że „Jezus Chrystus jest obliczem miłosierdzia Ojca”, gdyż „swoimi słowami, gestami i całą swoją osobą objawia miłosierdzie Boga". Natomiast miłosierdzie samo w sobie, to szczególna postać miłości, która przekracza ścisłą miarę sprawiedliwości (por. DiM 5). Według św. Jana Pawła II „,miłość ta w sposób szczególny daje o sobie znać w zetknięciu z cierpieniem, krzywdą, ubóstwem, w zetknięciu z całą historyczną «ludzką kondycją», która na różne sposoby ujawnia ograniczoność i słabość człowieka, zarówno fizyczną, jak i moralną" (DiM 3).

W ślad za swoim poprzednikiem Franciszek, we wprowadzeniu do bulli Misericordiae vultus, prawdzie o miłosierdziu nadaje jednoznaczny rys chrystologiczno-inkarnacyjny i trynitarny. Pisze bowiem, że „Jezus Chrystus jest obliczem miłosierdzia Ojca". W tym stwierdzeniu upatruje on syntezy wiary chrześcijańskiej, gdyż w Chrystusie, jako odwiecznym Słowie (Logosie), ,gdy nadeszła pełnia czasów” (por. Ga 4,4), Bóg bogaty w miłosierdzie „zesłał swojego Syna, narodzonego z Maryi Dziewicy, aby objawić nam w sposób ostateczny swoją miłość. [...] Jezus z Nazaretu swoimi słowami, gestami i całą swoją osobą objawia miłosierdzie Boga" (nr 1). Prawda o miłosierdziu ma stanowić też oś całej teologii, w tym także duchowości. Odnośnie do tego w liście do Wielkiego Kanclerza Papieskiego Uniwersytetu Katolickiego 
Argentyny z okazji stulecia założenia Wydziału Teologicznego (z 3 III 2015), Franciszek przypomniał, że współczesne uprawianie teologii ma się odbywać „w kluczu miłosierdzia”, które jest „samą istotą Ewangelii Jezusa”. Miłosierdzie urasta do istotnego klucza hermeneutycznego wszelkich rozważań teologicznych. Jest perspektywą, poza którą teologia odrywa się od życia chrześcijańskiego. Ono powinno być rzeczywistością centralną dla różnych dyscyplin teologicznych: „Bez miłosierdzia, nasza teologia, nasze prawo, nasza posługa pastoralna, popadają w niebezpieczeństwo biurokratycznej małoduszności bądź w ideologię, która ze swej natury chce oswoić tajemnicę. Pojmować teologię to pojmować Boga, który jest Miłością" (Franciszek, 2015c; Kotyński, 2017).

Obecny papież, przyjmując wszystko, co św. Jan Paweł II wyłożył na temat Bożego miłosierdzia, wyjaśnia, czym jest miłosierdzie nie tyle w Bogu samym, co w odniesieniu do ludzi ${ }^{4}$. W cytowanej bulli pisze bowiem, że ta tajemnica Bożego miłosierdzia jest „dla nas źródłem radości, ukojenia i pokoju. Jest warunkiem naszego zbawienia. Miłosierdzie: to jest słowo, które objawia Przenajświętszą Trójcę. Miłosierdzie: to najwyższy i ostateczny akt, w którym Bóg wychodzi nam na spotkanie. Miłosierdzie: jest podstawowym prawem, które mieszka w sercu każdego człowieka, gdy patrzy on szczerymi oczami na swojego brata, którego spotyka na drodze życia. Miłosierdzie: to droga, która łączy Boga z człowiekiem, ponieważ otwiera serce na nadzieję bycia kochanym na zawsze, pomimo ograniczeń naszego grzechu” (nr 2).

Kontynuując tę myśl, Franciszek za św. Tomaszem stwierdza, że „właściwe Bogu jest stosowanie miłosierdzia i w tym najwyraźniej wyraża się jego wszechmoc”. Toteż „miłosierdzie Boże nie jest znakiem słabości, lecz przejawem wszechmocy Boga" (MV 6), która przejawia się przede wszystkim w historii zbawienia - historii miłości Boga do człowieka. Jednak niewierność i słabość tego drugiego nadała jej charakter hamartiologiczny. Ojciec święty zaznacza więc, że „miłosierdzie wyraża zachowanie Boga w stosunku do grzesznika, ofiarując mu jeszcze jedną możliwość skruchy, nawrócenia i wiary" (MV 21). Ta pochylająca się nad ludzką nędzą miłość Boga Trójjedynego, z którą Franciszek wiąże atrybut czułości, najpełniej i konkretnie

${ }^{4}$ Pod tym kątem swoją teologię Bożego miłosierdzia uprawiał bł. Michał Sopoćko, który wydał czterotomowe dzieło pt. Miłosierdzie Boga w dziełach Jego (Londyn-Rzym-Paryż 19591967). Wnikliwe opracowanie jego nauczania prezentuje s. Marietta-Elżbieta Kruszewska w studium pt. Bóg miłosierny w przepowiadaniu bt. ks. Michała Sopoćki spowiednika św. s. Faustyny (Tarnów, 2015). Z kolei sługa Boży ks. Wincenty Granat, zajmując się problematyką miłosierdzia, kładł nacisk na chrystocentryzm. Pisał mianowicie o kulcie Chrystusa miłosiernego (Granat, 1970). 
objawiła się w Chrystusie. Dlatego „wpatrując się w Jezusa i w Jego miłosierne oblicze możemy doświadczyć miłości Trójcy Przenajświętszej” (MV 8). Ta miłość w Nim stała się „możliwa, widoczna i namacalna”, gdyż „Jego osoba jest niczym innym jak tylko miłością, która się daje za darmo" (MV 8). Jak zauważa Ojciec święty, wszystko, co Jezus czyni jako Bóg i Człowiek, jest „naznaczone miłosierdziem”, a zatem „wszystko w Nim mówi o miłosierdziu. Nie ma w Nim czegoś, co byłoby wyzute ze współczucia" (MV 8). W tym sensie zasadnym jest stwierdzenie, że Chrystus jest „Obliczem miłosierdzia”, jak głosi tytuł i pierwsze słowa bulli zapowiadającej Jubileuszowy Rok Miłosierdzia 5 .

Podsumowując ten etap rozważań dotyczący poznawczego aspektu duchowości miłosierdzia, warto jeszcze przywołać interesujący fragment wspomnianej książki Franciszka, w której Andrea Tornielli pyta go o znaczenie słów, jakie napisał w adhortacji Evangelii gaudium, a mianowicie, że „Boga nigdy nie męczy przebaczanie win" (nr 3). W odpowiedzi papież wyjaśnił, że Bóg nie męczy się przebaczaniem win, ,ponieważ jest Bogiem, ponieważ On jest miłosierdziem i ponieważ miłosierdzie jest Jego pierwszym atrybutem. To imię Boga” (Franciszek, 2016b). W innym zaś miejscu stwierdził, że „,miłosierdzie to dowód tożsamości naszego Boga. [...] to naprawdę objawienie tożsamości Boga" (Franciszek, 2016b).

Ojciec święty w bulli Misericordiae vultus zachęca więc, aby nieustannie kontemplować tę tajemnicę (por. nr 2), gdyż jest ona u podstaw duchowości miłosierdzia. Tylko to, co zostało poznane, może być uznane za wartość i pokochane.

\subsection{ASPEKT AKSJOLOGICZNO-AFEKTYWNY DUCHOWOŚCI MIŁOSIERDZIA}

W kształtowaniu postaw duchowych istotne znaczenie ma nie tylko poznawanie prawdy o Bogu i człowieku, ale również uznanie jej, a więc przyjęcie i wpisanie w swoją hierarchię wartości, co nie może się dokonać bez afektywnego zaangażowania podmiotu duchowego. Wobec tak doniosłej prawdy, jaką jest niczym nieuwarunkowana miłosierna miłość Boga, człowiek nie może być obojętny. Z tej racji Franciszek, w nawiązaniu do myśli św. Jana Pawła II na temat istoty Bożego miłosierdzia, już w pierwszych zdaniach bulli Misericordiae vultus wskazuje na aksjologiczne znaczenie tej prawdy dla współczesnego człowieka (nr 2), a zwłaszcza dla Kościoła. Nieco dalej

\footnotetext{
${ }^{5}$ Podobnie jak bł. Michał Sopoćko, również św. Jan Paweł II o Chrystusie uczył, że jest „wcielonym miłosierdziem” (por. DiM 2; Pyc, 2010).
} 
stwierdza, że „architrawem, na którym wspiera się życie Kościoła, jest miłosierdzie" (nr 10). Ono jest kryterium, za pomocą którego potwierdza on swoją wiarygodność wobec świata.

O tym, jak wielką wartość i znaczenie papież nadaje miłosierdziu w życiu i działaniu Kościoła, świadczy częstotliwość podejmowania tego tematu. Na przykład w adhortacji Evangelii gaudium pisze, że „Kościół powinien być miejscem bezinteresownego miłosierdzia, w którym wszyscy mogą się czuć przyjęci, kochani, w którym mogą doświadczyć przebaczenia i być zachęceni, aby żyć zgodnie z dobrym życiem Ewangelii” (nr 114). W innym miejscu tego dokumentu stwierdza, że prowadząc misję ewangelizacyjną, Kościół „,̇ywi nieprzebrane pragnienie ofiarowania miłosierdzia jako owoc doświadczenia nieskończonego miłosierdzia Ojca i jego dynamicznej, wszystko ogarniającej mocy" (EG 24). Idąc tym tropem Franciszek z pewnym upodobaniem parokrotnie porównuje Kościół do szpitala polowego. Na przykład podczas spotkania z kapłanami diecezji rzymskiej dnia 6 III 2014 r. mówił: „Dzisiaj Kościół powinniśmy wyobrażać sobie jak «szpital polowy». [...] Trzeba leczyć rany, liczne rany! Bardzo wiele ran! Jest bardzo wiele osób zranionych przez problemy materialne, przez skandale, także w Kościele... Ludzi zranionych przez ułudy świata... My księża musimy być tam, blisko tych ludzi. Miłosierdzie znaczy przede wszystkim leczyć rany. Kiedy ktoś jest zraniony, potrzebuje natychmiast tego, a nie analiz, takich jak wskániki cholesterolu, poziomu cukru we krwi... Jeśli jest rana, zalecz ranę, a potem przyjrzymy się analizom. Później będzie leczenie specjalistyczne, ale najpierw trzeba zaleczyć otwarte rany. Dla mnie to w danej chwili jest ważniejsze. A są także rany ukryte, ponieważ są ludzie, którzy oddalają się, żeby nie pokazywać ran..." (Franciszek, 2014c).

Aksjologiczny wymiar duchowości miłosierdzia, jakie Kościół święty ma obowiązek świadczyć człowiekowi, który jest jego drogą (por. RH 14), szczególnie dostrzegalny jest w posłudze odpuszczania grzechów. A ponieważ jak zauważa papież - współcześnie wiele osób chętniej niż z sakramentu pokuty korzysta z usług „magów i chiromantów”, szukając „zbawienia wszędzie, gdzie to możliwe”, a przede wszystkim kogoś, „kto ich wysłucha”, dlatego posługa spowiadania odgrywa dziś niezwykle ważną rolę i na spowiednikach spoczywa wielka odpowiedzialność. ,Jeśli osoby te [które zostały zranione - przyp. aut.] nie poczują dzięki spowiednikom Bożej miłości i miłosierdzia, oddalą się i może już nigdy nie wrócą" (Franciszek, 2014c). A zatem ,powołaniem Kościoła jest rozdawać miłosierdzie” (Franciszek, 2014c). On „nie jest na świecie po to, by potępiać, lecz by pozwolić na spotkanie 
z tą przenikającą do trzewi miłością, jaką jest Boże miłosierdzie" - stwierdza Franciszek (Franciszek, 2014c).

Do tego jednak, aby docenić wartość Bożego miłosierdzia i doświadczyć go przez pokorna posługę Kościoła, konieczna jest właściwa postawa grzesznika, który pragnie i poszukuje miłosierdzia. Nie wystarczy z jego strony samouznanie grzechu tak, jakby to była plama na ubraniu. Dlatego papież podkreśla, że konfesjonał nie powinien być „pralnią”, gdzie szybko można pozbyć się plamy i wszystko wraca do wcześniejszego stanu. „Grzech to jednak coś więcej niż plama. Grzech jest zranieniem, a rana musi być opatrzona, leczona" (Franciszek, 2014c) ${ }^{6}$. Skutecznym zaś lekarstwem na ranę grzechu jest ufność, która w świetle objawień św. Faustyny Kowalskiej jest zasadniczą dyspozycją pozwalającą doświadczyć Bożego miłosierdzia (por. Dz 1074, 1182, 1485, 1578). Ojciec święty przestrzega zatem kapłanów, aby konfesjonału nie traktowali jak ,sali tortur”, ale jako „miejsce miłosierdzia Pana, zachęcającego nas do czynienia możliwego dobra" (EG 44). Miłosierdzie bowiem - jak mówił Franciszek podczas audiencji generalnej 10 IX 2014 r. - ,pokonuje każdy mur, każdą barierę i skłania cię do szukania zawsze oblicza człowieka, osoby. I właśnie miłosierdzie zmienia serce i życie, może odrodzić osobę i umożliwić jej włączenie się w nowy sposób w społeczeństwo" (Franciszek, 2014a). Konieczne jest zatem pełne ufności otwarcie się na dar Bożego miłosierdzia, którego nie zastąpi żadna psychoterapia. „Miłosierdzie istnieje, ale jeśli nie chcesz go przyjąć... Jeśli nie uznajesz, że jesteś grzeszny, to znaczy, że nie chcesz przyjąć miłosierdzia, nie czujesz byś go potrzebował. - zauważa Franciszek w rozmowie z A. Torniellim - [...] Albo możesz woleć swoje rany, rany grzechu, możesz postępować jak pies: lizać je językiem, wylizywać rany. To choroba narcyzmu, która przynosi gorycz. To znajdowanie przyjemności, chorej przyjemności, w goryczy" (Franciszek, 2016b). Tymczasem właściwą drogą do doświadczenia miłosierdzia, sugerowaną przez Ojca świętego, jest pełne ufności uznanie siebie grzesznikiem (por. RP 13), które, choć jest trudną drogą nawrócenia, to jednak jest pewnego rodzaju łaską. „To łaska, która zostaje ofiarowana. Bez łaski

\footnotetext{
${ }^{6} \mathrm{~W}$ związku z problematyką miłosierdzia Ojciec święty porusza ważną kwestię moralnych dyspozycji penitenta. Uważa, że poważną przeszkodą do tego, aby doświadczyć Bożego miłosierdzia jest niemoralność, która w odróżnieniu od grzechu „nie jest czynem, ale stanem, stanem osobowym i społecznym, w którym ktoś przyzwyczaja się żyć”. Zaznacza także, że człowiek ,niemoralny nie zna pokory, nie uważa, by potrzebował pomocy, prowadzi podwójne życie. [...] Osobę niemoralną męczy proszenie o przebaczenie, zaczyna ona wierzyć, że nie musi już o nie prosić" (Franciszek, 2014c).
} 
można dojść co najwyżej do tego, by powiedzieć: jestem ograniczony, mam swoje ograniczenia, to są moje błędy" (Franciszek, 2016b).

Skoro mówimy o afektywno-aksjologicznym wymiarze duchowości miłosierdzia, to warto w podsumowaniu wspomnieć jeszcze o tym, że Franciszek dostrzega jego doniosłą wartość także w życiu małżeńskim i rodzinnym. Stwierdza bowiem, że ,rodzina jest pierwszą szkołą miłosierdzia, ponieważ to tam jesteśmy kochani i tam uczymy się kochać, doświadczamy przebaczenia i uczymy się przebaczać" (Franciszek, 2016b; Niemira, 2019). Zatem rodzina jako pierwsza powinna żyć duchowością miłosierdzia.

\subsection{ASPEKT PRAKTYCZNO-DZIAŁANIOWY DUCHOWOŚCI MIŁOSIERDZIA}

Gdy mówi się o duchowości, to najczęściej przedmiotem uwagi staje się jej praktyczno-działaniowy aspekt, do czego zresztą skłaniają słowa św. Jakuba Apostoła, mówiące o tym, że ,wiara, jeśli nie byłaby połączona z uczynkami, martwa jest sama w sobie" (Jk 2,17), byłaby bezowocna (por. Jk 2,20) i byłaby jak ciało bez ducha (por. Jk 2,26). Nie dziwi zatem to, że Franciszek, zwłaszcza w kontekście Nadzwyczajnego Jubileuszu Miłosierdzia, szczególnie dużo uwagi przywiązywał do tego, co często nazywane jest miłosierdziem ludzkim, podejmowanym w odpowiedzi na doznawane miłosierdzie Boże. Oczywiście, chodzi tu głównie o klasyczny katalog uczynków względem ciała i względem duszy. „Jest moim gorącym życzeniem - pisze papież - aby chrześcijanie zastanowili się podczas Jubileuszu nad uczynkami miłosierdzia względem ciała i względem ducha. Będzie to sposób na obudzenie naszego sumienia, często uśpionego w obliczu dramatu ubóstwa, a także na wchodzenie coraz głębiej w serce Ewangelii, gdzie ubodzy są uprzywilejowani przez Boże miłosierdzie" (MV 15; Kucharski, 2016; Paszkowska, 2016). Jak dalej zaznacza Ojciec święty, pełnienie uczynków miłosierdzia jest ważnym kryterium rozpoznawczym uczniów Chrystusa. By więc żyć duchowościa miłosierdzia, nie wystarczy - jak mówił św. Jan Paweł II do zakonnic w krakowskich Łagiewnikach 7 VI 1997 r. - samo głoszenie prawdy o Bożym miłosierdziu czy modlitwa o nie, ale nade wszystko potrzeba dzieł miłosierdzia. Nie można więc zaniedbywać żadnego z tych wymiarów apostolstwa związanego z Bożym miłosierdziem (Jan Paweł II, 2008), gdyż - jak przypomina Franciszek - w świetle Ewangelii pełnienie uczynków miłosierdzia ze względu na Chrystusa wobec ludzi najbardziej potrzebujących będzie przedmiotem sądu po śmierci (por. Mt 25,31-45). W tym kontekście papież, poszerzając nieco katechizmowy katalog uczynków miłosierdzia, każe zapytać się o to, „czy pomogliśmy przezwyciężyć wątpliwości, które rodzą strach 
i stają się źródłem samotności; czy potrafiliśmy pokonać niewiedzę, w której żyją miliony osób, a przede wszystkim dzieci pozbawione koniecznej pomocy, aby wyzwolić się z ubóstwa; czy okazaliśmy bliskość samotnemu i uciśnionemu; czy przebaczyliśmy temu, kto nas obraża, i odrzuciliśmy wszelką formę urazy i nienawiści, która prowadzi do przemocy; czy byliśmy cierpliwi na wzór Boga, który jest tak bardzo cierpliwy wobec nas; i wreszcie, czy powierzaliśmy Panu w modlitwie naszych braci i siostry" (MV 15).

Na temat uczynków miłosierdzia Franciszek pisał również w orędziu na Wielki Post 2016 r. (z 4 X 2015). Nosi ono znamienny tytuł: „«Chcę raczej miłosierdzia niż ofiary» (Mt 9,13). Uczynki miłosierdzia w Roku Jubileuszowym”. Czytamy tam między innymi, że „poprzez uczynki względem ciała dotykamy ciała Chrystusa w braciach i siostrach, którzy potrzebują, by ich nakarmić, odziać, przyjąć do domu i nawiedzić, a poprzez uczynki duchowe - dawanie rad, pouczanie, darowanie uraz, upominanie i modlitwę, obcujemy bardziej bezpośrednio z naszą własną grzesznością. Z tego powodu uczynków względem ciała i względem ducha nigdy nie należy od siebie oddzielać" (Franciszek, 2015b).

Swoimi wypowiedziami, niekiedy z nutą sarkazmu, papież przestrzega przed fałszywą, angeliczną i pseudo-spirytualistyczną duchowością, która skupia się niemal wyłącznie na modlitwie i aktach pobożności. W Evangelii gaudium czytamy, iż ,należy odrzucać pokusę duchowości skupionej na wewnętrznych, indywidualnych przeżyciach, którą trudno byłoby pogodzić z wymogami miłosierdzia, a ponadto z logiką Wcielenia" (nr 262). Nieodzownym wymiarem zdrowej duchowości chrześcijańskiej jest natomiast czynna miłość bliźniego, która powinna wypływać z doświadczenia miłości miłosiernej Boga, a nie kierować się jedynie współczuciem. Pomiędzy bowiem miłosierdziem, będącym przejawem dojrzałego życia duchowego, a współczuciem zachodzi kolosalna różnica. Papież zauważa, że „miłosierdzie jest boskie, jest bardziej związane z sądem nad naszym grzechem”, natomiast „współczucie ma bardziej ludzkie oblicze" (Franciszek, 2016b). Oznacza to, że samo współczucie nie jest wystarczającą motywacją do podejmowania dzieł miłosierdzia, które w tym przypadku nie różniłyby się od zwykłej dobroczynności. Tymczasem chodzi o ewangeliczny nakaz świadczenia miłości i miłosierdzia (por. Mt 25,40). Konieczna jest więc motywacja nadprzyrodzona i dzielenie się doświadczeniem miłosierdzia Boga (miłosierdziem doznawanym). Kościół bowiem ,żywi nieprzebrane pragnienie ofiarowania miłosierdzia jako owoc doświadczenia nieskończonego miłosierdzia Ojca i jego dynamicznej, wszystko ogarniającej mocy" (EG 24). 
Pełnienie uczynków miłosierdzia w różnej postaci i zależnie od okoliczności, jako praktyczno-działaniowy wymiar życia duchowego, jest powinnością każdego chrześcijanina. Kościół natomiast ma za zadanie wychowywać ludzi do takiej postawy, o czym przypomniał Franciszek podczas audiencji generalnej 10 IX 2014 r. Mówiąc o wychowawczej funkcji Kościoła, zauważył, że „dobry wychowawca stawia na to, co istotne. Nie wdaje się w szczegóły, ale chce przekazać to, co liczy się naprawdę, aby dziecko czy uczeń znaleźli sens i radość życia. [...] A tym, co istotne według Ewangelii, jest miłosierdzie. Istotą Ewangelii jest miłosierdzie. [...] Czy może istnieć chrześcijanin, który nie jest miłosierny? Nie. Chrześcijanin siłą rzeczy musi być miłosierny, gdyż to jest istotą Ewangelii. A Kościół, wierny temu nauczaniu, musi powtarzać to samo swoim dzieciom: «Bądźcie miłosierni», tak jak miłosierny jest Ojciec i jak był miłosierny Jezus” (Franciszek, 2014a).

Widzimy zatem, że temat miłosierdzia $z$ entuzjazmem podejmowany na różne sposoby z okazji Nadzwyczajnego Jubileuszu Miłosierdzia, pozostaje wciąż aktualny dla tożsamości Kościoła i wynikającej z niej działalności, a tym samym ważny dla życia duchowego.

\section{LITURGICZNY WYMIAR DUCHOWOŚCI MIŁOSIERDZIA}

W chrześcijaństwie kult jako taki, mający za przedmiot którąś z Boskich Osób lub Jej przymioty, choć obejmuje różne formy pobożności ludowej, to przede wszystkim i najpełniej wyraża się poprzez czynności liturgiczne, do których w pierwszej kolejności należy sprawowanie sakramentów świętych, a zwłaszcza Eucharystii. Kult liturgiczny ma swój rytm na ogół w ramach cyklu rocznego ${ }^{7}$. Nie inaczej jest z kultem miłosierdzia Bożego, co potwierdza zarówno historia objawień św. Faustyny, jak i późniejszy jego rozwój.

Kult Jezusa Miłosiernego - według objawień św. Faustyny - od początku pozostawał w ścisłym związku z liturgią. Liczne chrystofanie i przesłania, jakie otrzymywała Sekretarka Bożego miłosierdzia miały miejsce podczas Eucharystii lub w związku z nią, na przykład podczas adoracji Najświętszego Sakramentu, albo w ramach różnych obchodów w ciągu roku liturgicznego.

7 Trudność w zdefiniowaniu kultu wynika z jego wieloznaczności. Niemniej jednak wydane przez Kongregację do spraw Kultu Bożego i Dyscypliny Sakramentów Dyrektorium o pobożności ludowej i liturgii. Zasady i wskazania (Pallottinum, 2003) rozróżnia pomiędzy kultem liturgicznym a pobożnością ludową (zob. nr 4; Nadolski, 2006). 
Mówi się zatem, że Eucharystia jest miejscem doświadczenia miłosierdzia Bożego (Zarzycki, 2018).

Zaraz po wizji Pana Jezusa, jaka miała miejsce w Płocku 22 II 1931 r., a została odwzorowana w obrazie pędzla Eugeniusza Kazimirowskiego, św. Faustyna otrzymała wyraźne polecenie, aby w Kościele ustanowiono osobne święto ku czci Bożego miłosierdzia w drugą niedzielę wielkanocną (Dz. 49), która ma być nazwana „świętem miłosierdzia” (Dz. 88, 150, 742). Ustanowienie tego święta przez św. Jana Pawła II przy okazji kanonizacji Apostołki miłosierdzia w ramach obchodów Jubileuszu Roku 2000, poprzedzone pozwoleniem na jego lokalne obchodzenie, między innymi w archidiecezji krakowskiej, nie wymagało żadnych zmian w posoborowych tekstach liturgicznych przewidzianych na drugą niedzielę Wielkanocy. Okazuje się bowiem, że nie tylko w liturgii tego dnia, ale w każdej Mszy świętej temat Bożego miłosierdzia przewija się nieustannie. W samych tylko częściach stałych znajdujemy około 30 razy odwołanie się do miłosierdzia Bożego, na przykład $\mathrm{w}$ akcie pokuty, następnie $\mathrm{w}$ inwokacji niemal każdej $\mathrm{z}$ prefacji, w poszczególnych modlitwach eucharystycznych, a także w modlitwie po „Ojcze nasz” i przed Komunią świętą. Temat Bożego miłosierdzia często pojawia się również w częściach zmiennych, to jest w: antyfonach na wejście, kolektach, modlitwach nad darami, w antyfonach na Komunię i modlitwach po Komunii świętej. W sumie w Mszale rzymskim dla diecezji polskich znaleźć można około 360 odwołań do Bożego miłosierdzia lub miłosiernego Boga Ojca. Z oczywistych względów tematyka ta najczęściej pojawia się w okresie Wielkiego Postu. W ten sposób celebracja Mszy świętej, która jest najlepszą szkołą wiary (por. KKK 1068. 1074), kształtuje świadomość jej uczestników, że całe misterium zbawcze, uobecniane w sprawowanej liturgii, jest dziełem Boga bogatego w miłosierdzie. Jest zarazem najpełniejszym uwielbieniem Go w tym przymiocie Jego Boskiej natury, a więc aktem najwyższego kultu. Można zatem wprost mówić o miłosierdziowym wymiarze liturgii.

$\mathrm{Na}$ ścisły związek miłosierdzia z liturgią zwrócił uwagę Franciszek w liście apostolskim Misericordia et misera, zachęcając do tego, aby „,celebrować miłosierdzie” (Warzeszak, 2017). W liturgii bowiem - jak czytamy - „miłosierdzie jest nie tylko wielokrotnie przywoływane, ale jest rzeczywiście przyjmowane i przeżywane. Od początku do końca celebracji eucharystycznej miłosierdzie powraca wiele razy $\mathrm{w}$ dialogu między modlitewnym zgromadzeniem a sercem Ojca, które raduje się, gdy może rozlewać swoją miłość miłosierną" (MeM 5). Stwierdzając to, papież dokonuje przeglądu tekstu Mszy świętej pod kątem miłosierdzia Bożego. Dochodzi do trafnego wniosku, że 
„celebracja miłosierdzia osiąga swój szczyt w Ofierze Eucharystycznej, pamiątce paschalnego misterium Chrystusa, z którego wypływa zbawienie dla każdego człowieka, dla historii i dla całego świata. Krótko mówiąc, każdy moment celebracji eucharystycznej odwołuje się do Bożego miłosierdzia" (MeM 5; Sawa, 2018).

Jak słusznie zauważa Franciszek, doświadczenie tajemnicy Bożego miłosierdzia nie ogranicza się do samej liturgii Mszy świętej. „W całym życiu sakramentalnym otrzymujemy miłosierdzie w obfitości” (MeM 5). Szczególne znaczenie mają dwa sakramenty, nazywane sakramentami uzdrowienia, to znaczy: pojednanie i namaszczenie chorych. W formułach obydwu sakramentów mocno wybrzmiewa odwołanie się do Bożego miłosierdzia. Zwłaszcza w sakramencie pokuty dokonuje się wspomniana „celebracja miłosierdzia” (MeM 8). „Zatem w modlitwie Kościoła odniesienie do miłosierdzia nie jest jedynie pouczeniem, ale jest wysoce performatywne/sprawcze/skuteczne, to znaczy, że gdy wypowiadamy je z wiara, jest nam ono udzielane. Kiedy je wyznajemy jako żywe i realne, rzeczywiście nas przemienia" (MeM 5). Inaczej mówiąc, w liturgiczno-sakramentalnej posłudze Kościoła wierny realnie doświadcza uprzedzającej miłości Boga, która ,jest większa niż grzech” - jak uczył św. Jan Paweł II (por. ReP 13). Nieco inaczej wyraża tę myśl obecny papież pisząc, że zanim ujawniła się prawda o grzechu, została nam najpierw objawiona miłość, z jaką Bóg stworzył świat i ludzi. „Miłość jest pierwszym aktem, poprzez który Bóg daje siebie poznać i wychodzi nam na spotkanie" (MeM 5). Uprzedniość Bożej miłości, która pochylając się nad nędzą człowieka przybiera kształt miłosierdzia (por. DiM 14), jest - zdaniem Franciszka - zasadniczym motywem do ufności. Ta zaś, według objawień św. Faustyny Kowalskiej, jest „naczyniem”, którym czerpie się łaski ze źródła miłosierdzia (por. Dz. 1485).

Oprócz liturgii eucharystycznej i sakramentów w kształtowaniu postaw duchowych wielką rolę odgrywa Słowo Boże. Jak napisał Benedykt XVI w adhortacji Verbum Domini, ono „leży bowiem u podstaw każdej autentycznej duchowości chrześcijańskiej” (nr 86). Franciszek zatem także w słuchaniu Słowa Bożego, zwłaszcza w ramach celebracji eucharystycznej, upatruje możliwości odkrywania prawdy o Bożym miłosierdziu i doświadczania go. W tym kontekście usilnie poleca kapłanom dbałość o przygotowywanie homilii. Przepowiadając Słowo Boże, mają oni przedstawiać się jako ci, którzy na sobie doświadczyli Bożego miłosierdzia, co jest warunkiem wiarygodności ich posługi kapłańskiej. „Życie miłosierdziem jest zatem najlepszą drogą, by stało się ono prawdziwym głoszeniem pocieszenia i nawrócenia w życiu duszpasterskim" (MeM 6). 
Widzimy zatem, że - zdaniem Franciszka - kształtowanie postaw miłosierdzia, czyli duchowość miłosierdziowa, obficie czerpie z liturgii i Słowa Bożego.

Charakteryzując w głównych rysach duchowość miłosierdzia zgodnie z tym, jak ujmuje ją papież Franciszek, nie można pominąć ważnej roli Maryi. Święty Jan Paweł II, w nawiązaniu do wielowiekowej tradycji Kościoła, nazywał Ją Matką Miłosierdzia, Matką Bożą Miłosierdzia lub Matką Bożego Miłosierdzia (por. DiM 9). Podobnie czyni obecny papież, wielokrotnie przywołując Jej postać w kontekście podejmowanej tematyki miłosierdzia. Wymownym gestem było sprowadzenie ikony maryjnej zwanej „Bramą Miłosierdzia" z jednego z kościołów w Jarosławiu na czas inauguracji Jubileuszowego Roku Miłosierdzia w Bazylice św. Piotra. Podobnie jak jego poprzednicy, Franciszek niemal każde swoje wystąpienie i dokument kończy maryjną inwokacja. Na przykład w zakończeniu bulli Misericordiae vultus napisał, że nikt tak jak Maryja nie poznał ,głębi tajemnicy Boga, który stał się człowiekiem. Wszystko w Jej życiu zostało ukształtowane przez obecność miłosierdzia, które stało się ciałem. Matka Ukrzyżowanego i Zmartwychwstałego weszła do sanktuarium miłosierdzia Bożego, ponieważ duchowo uczestniczyła w tajemnicy Jego miłości” (nr 24) ${ }^{8}$. Przewidziana na Matkę Syna Bożego, Maryja była w zamysłach Bożej Opatrzności przygotowywana do tego, by „,stała się Arką Przymierza między Bogiem i ludźmi”. Zachowała więc w swoim sercu Boże miłosierdzie w doskonałej harmonii ze swoim Synem Jezusem. W tym sensie faktycznie jest Matką Bożego Miłosierdzia. Mamy więc pełne prawo prosić Ją - konkluduje Franciszek - ,,aby nigdy nie przestała zwracać ku nam swoich miłosiernych oczu i uczyniła nas godnymi kontemplowania oblicza miłosierdzia - Jej Syna Jezusa" (MV 24).

Maryja zatem jest doskonałym wzorem naśladowania szczególnie dla tych wierzących, którzy chcą pielęgnować i pogłębiać duchowość miłosierdzia.

${ }^{8}$ Interesującym do tego komentarzem mogą być słowa kard. Waltera Kaspera z książki pt. Miłosierdzie klucz do chrześcijańskiego życia (Poznań: Wydawnictwo Święty Wojciech, 2014, 225. 227. 236): „Maryja stanowi archetyp Kościoła, jest zatem również archetypem chrześcijańskiego miłosierdzia. [...] Jest narzędziem Bożego miłosierdzia dzięki swojemu pełnemu wiary tak, które wypowiada wobec najpierw zaskakującego, niepojętego dla niej i przerastającego ją przesłania anioła. [...] Maryja mówi nam i pokazuje nam, że Ewangelia o Bożym miłosierdziu w Jezusie Chrystusie to najlepsze, co może nam zostać powiedziane i co będziemy mogli kiedykolwiek usłyszeć; a jednocześnie najpiękniejsze, co może istnieć...”. 
Papież zwraca uwagę, że „miłosierdzie nie może być bowiem jaką́s dygresją w życiu Kościoła, ale stanowi samo jego życie, czyniąc widoczną i namacalną głęboką prawdę Ewangelii. Wszystko objawia się w miłosierdziu; wszystko się rozstrzyga w miłosiernej miłości Ojca" (MeM 1). Nie jest to więc duchowość opcjonalna, jedna $\mathrm{z}$ wielu form życia duchowego, ale $\mathrm{w}$ jakimś sensie samo jądro duchowości chrześcijańskiej, znajdującej wyraz w praktyce życia na co dzień. Miłosierdzie bowiem ,jest tym konkretnym działaniem miłości, które przebaczając, przekształca i zmienia życie" (MeM 2). Franciszek wskazuje ją jako duchowość przyszłości, zdolną dynamizować dzieło nowej ewangelizacji (por. MeM 5).

\section{BIBLIOGRAFIA}

Chmielewski, Marek (2006). „Duchowość a horyzontalizm społeczeństwa europejskiego”. Soter (Kowno). 17: 19-26.

Chmielewski, Marek. (2010a). „Maryjny wymiar duchowości katolickiej. Wybór czy konieczność?". Salvatoris Mater, 12, 1-2: 11-23.

Chmielewski, Marek. (2010b). „Potrzeba metodologii w teologii duchowości”. Duchowość w Polsce, 12: 29-39.

Chmielewski, Marek. (2014). „Ufność w Boże miłosierdzie odpowiedzią na chorobę horyzontalizmu". Duchowość w Polsce, 16: 165-175.

Franciszek. (2013). Adhortacja „Evangelii gaudium” o głoszeniu Ewangelii we wspótczesnym świecie. Watykan.

Franciszek. (2014a). Audiencja generalna (10 IX 2014), https://opoka.org.pl/biblioteka/W/WP/ franciszek_i/audiencje/ag_10092014.html [21.01.2021]. Watykan.

Franciszek. (2014b). List apostolski do wszystkich osób konsekrowanych z okazji Roku Życia Konsekrowanego 2014. Watykan.

Franciszek. (2014c). Address of pope Francis to the parish priests of the diocese of Rome (4 III 2014), http://www.vatican.va/content/francesco/en/speeches/2014/march/documents/ papa-francesco_20140306_clero-diocesi-roma.html [21.01.2021]. Watykan.

Franciszek. (2014d). Orędzie na Światowy Dzień Młodzieży 2014. Watykan.

Franciszek. (2015a), Bulla Misericordiae vultus (11 IV 2015). Watykan.

Franciszek. (2015b). Orędzie na Wielki Post 2016 (4 X 2015), https://opoka.org.pl/biblioteka/ W/WP/franciszek_i/przemowienia/post2016-or-04102015.html [21.01.2021]. Watykan.

Franciszek. (2015c). Letter of his holiness pope Francis to the Grand Chancellor of the „Pontificia Universidad Católica Argentina" for the $100^{\text {th }}$ anniversary of the founding of the Faculty of theology (3 III 2015), http://www.vatican.va/content/francesco/en/letters/2015/do cuments/papa-francesco_20150303_lettera-universita-cattolica-argentina.html,[21.01.2021]. Watykan.

Franciszek. (2016a). List apostolski Misericordia et misera (20 XI 2016). Watykan.

Franciszek. (2016b). Miłosierdzie to imię Boga. Rozmowa z Andreq Torniellim. Kraków. 
Granat, Wincenty. (1970). „Kult Boga miłosiernego przez Chrystusa i w Chrystusie”. W: Wincenty Granat (red.). Ewangelia miłosierdzia, 389-409. Poznań-Warszawa.

Jan Paweł II. (1980). Encyklika o Bożym miłosierdziu „Dives in misericordia” (30 XI 1980). Watykan.

Jan Paweł II. (2008). Dzieła zebrane. T. 9. Homilie i przemówienia z pielgrzymek - Europa, część 1 - Polska. Kraków.

Jędrzejski, M. (2017). „Posługa miłosierdzia w nauczaniu Benedykta XVI”. W: Roman Ceglarek, Andrzej Kuliberda (red.). Badźcie świadkami miłosierdzia, 51-63. Częstochowa.

Kasper, Walter. (2014). Miłosierdzie klucz do chrześcijańskiego życia. Poznań.

Kongregacja do spraw Kultu Bożego i Dyscypliny Sakramentów. (2003). Dyrektorium o pobożności ludowej i liturgii. Zasady $i$ wskazania, Pallottinum.

Kotyński, Marek. (2017). „Miłosierdzie w teologii duchowości”. Warszawskie Studia Teologiczne, 30, 3-4: 32-51.

Kowalska, Faustyna. (1995). Dzienniczek. Miłosierdzie Boże w duszy mojej (wyd. 4). Warszawa.

Kruszewska, Marietta Elżbieta. (2015). Bóg miłosierny $w$ przepowiadaniu bt. ks. Michała Sopoćki spowiednika św. s. Faustyny. Tarnów.

Kucharski, Jacek. (2016). „Biblijne źródła uczynków miłosierdzia względem ciała”. Zeszyty Formacji Katechetów, 62, 2: 56-69.

Matulewicz, Elżbieta. (2007). Miłosierdzie Boże w charyzmacie Zgromadzenia Księży Marianów. Lublin.

Nadolski, Bogusław. (2006). Leksykon liturgii. Poznań.

Niemira, Artur. (2019). „Wymóg miłosierdzia w działalności duszpasterstwa rodzin. Refleksje wokół adhortacji 'Amoris laetitia'”. Studia Wtoctawskie, 21: 257-274.

Paszkowska, Teresa. (2016). „Uczynki miłosierne względem ciała - uduchowione powinności”. Duchowość w Polsce, 18: 145-156.

Pyc, Marek. (2010). „Chrystologia”. W: Krzysztof Góźdź, Krzysztof Guzowski (red.). Dogmatyka $w$ perspektywie Bożego miłosierdzia, 103-116. Lublin.

Sawa, Przemysław. (2018). „Wybrane aspekty miłosierdzia w nauczaniu papieża Franciszka”. W: Przemysław Sawa (red.). Miłosierdzie. Próba spojrzenia interdyscyplinarnego, 129-153. Katowice.

Warzeszak, Józef. (2017). „Miłosierny styl życia chrześcijańskiego według papieża Franciszka”. Warszawskie Studia Teologiczne, 30, 1: 39-87.

Warzeszak, Józef. (2016). „Bliskość Boga wyrazem jego miłości i miłosierdzia w ujęciu Benedykta XVI". Warszawskie Studia Teologiczne, 29, 1: 7-30.

Wejman, Henryk. (1999). Zbawcza wartość duchowości mitosierdzia. Poznań.

Zarzycki, Stanisław T. (2018). „Eucharystia 'miejscem' kultu i doświadczenia miłosierdzia Bożego”. W: Przemysław Sawa (red.). Miłosierdzie. Próba spojrzenia interdyscyplinarnego, 154-177. Katowice.

\section{DUCHOWOŚĆ MIŁOSIERDZIA WEDŁUG PAPIEŻA FRANCISZKA}

St reszcze n i e

Za sprawą ostatnich papieży, a szczególnie Franciszka, charakterystycznym rysem Kościoła katolickiego w trzecim tysiącleciu jest kult miłosierdzia Bożego. Domaga się on kształtowania 
odpowiednich postaw duchowych, które we współczesnej teologii duchowości opisuje się przez wskazanie na ich aspekt poznawczy, aksjologiczno-afektywny i praktyczno-działaniowy.

Tematyka miłosierdzia tak głęboko przenika życie Kościoła, że można mówić nie tylko o duchowości miłosierdzia, ale o miłosierdziowym wymiarze duchowości chrześcijańskiej.

Kult Bożego miłosierdzia jest ściśle związany z liturgią, dlatego - zwłaszcza liturgia eucharystyczna - ma również miłosierdziowy wymiar. Kształtowanie postaw miłosierdzia znajduje więc w niej swe źródło.

Słowa kluczowe: duchowość; miłosierdzie; postawa duchowa; liturgia; papież Franciszek. 